\title{
Genome-wide association study (GWAS) of seed germination-related traits in rice and identification of candidate genes
}

Rahele Panhabadi

Shahid Beheshti University

Asadollah Ahmadikhah ( $\nabla$ a_ahmadikhah@sbu.ac.ir)

Shahid Beheshti University https://orcid.org/0000-0001-5100-9740

Naser Farokhi

Shahid Beheshti University

Nadali Bagheri

Sari Agricultural Sciences and Natural Resources University

\section{Research Article}

Keywords: germination, Oryza sativa, quantitative trait loci (QTL), seed, single nucleotide polymorphism (SNPs)

Posted Date: March 15th, 2021

DOI: https://doi.org/10.21203/rs.3.rs-312154/v1

License: (c) (i) This work is licensed under a Creative Commons Attribution 4.0 International License. Read Full License 


\section{Abstract \\ Background}

Genome-wide association study (GWAS) has become an accepted and powerful method for understanding the associations between phenotypes and genotypes. In agricultural production, uniform and rapid germination is an important prerequisite in crop production. Here, a rice (Oryza sativa L.) GWAS with 33,934 SNPs (MAF > 0.05) for eight germination traits including germination percentage (GP), shoot (SL) and root length (RL), root (RFW) and shoot fresh weight (SFW), root (RDW) and shoot (SDW) dry weight, and number of days to germinate (NDG) was performed to define genomic regions influencing seed germination.

\section{Results}

Loci (43) with 70 significant germination-associated markers were detected across all rice chromosomes. Some of novel candidate associated genes were: LOC_Os01g26210 (OsWAK6) co-located with qGR-1 that is seed vigor QTL, LOC_Os07g23944 (GH31) with an a-glucosidases /starch lyase activity; id7000519 marker that corresponds to a gene cluster containing glutathione $S$ transferase and glucan endo-1,3- $\beta$-glucosidase co-located with qAG3 germination-related marker, LOC_Os06g47640 (calmodulin-related calcium sensor protein 29) involved in the inhibition of ABA during seed germination, and id4006430 marker that corresponds to a gene cluster containing three GH17 hydrolytic enzyme that are co-located with qHD4 and qGI1 markers.

\section{Conclusion}

The germination process is an initial and important step in the production of agricultural products, especially for rice, which is a crop plant that is grown in flooded lands. Here, the genetic diversity of rice genotypes was put under scrutiny for germination. Our GWAS results identified several likely candidate genes for germination traits that will greatly contribute to our understanding of the genetic complexity underlying the corresponding traits. The associated genes with the germination traits can be generally classified as hydrolytic enzymes and regulatory proteins that can directly or indirectly influence germination.

\section{Background}

Successful germination, with direct association to crop yield, is an important step in seedlings establishment (Almansouri et al. 2001). Cereals seeds have a similar structure that include seed coat, bran, starchy endosperm and embryo (Linkies et al. 2010). Germination in cereals initiates with the activation of hydrolytic enzymes present in aleurone following imbibition and uptake of water. The enzymes, mainly amylases and glucanases, digest the starch present in endosperm to release glucosyl residues that then can be transported through scutellum to embryo. The embryo uses glucose as energy source to germinate (Joshi 2018). The germination is regulated by abscisic acid (ABA) and gibberellins (GAs) with contradictory effect on the process: ABA has inhibitory- (Nambara et al. 2010), while GAs have stimulatory- roles in hydrolytic enzyme secretion (Mrva et al. 2006; Guzmán-Ortiz et al. 2019). Other factors such as cGMP, calcium, calmodulin, and protein kinases regulate the aleurone response to hormones during germination (Ritchie et al. 2000). In addition to the starch-degrading enzymes, other enzymes that break down cell wall components, including enzymes such as arabinoxylan hydrolases, xylopyranosidase, 
been shown to be increased during germination (Guzmán-Ortiz et al. 2019; Ha et al. 2018; Andriotis et al. 2016; González-Calle et al. 2015; Gomez et al. 2009; Grant et al. 2003; Leubner-Metzger, 2003; Caspers et al. 2001). Catalase has been suggested to be involved in the promotion of dormant seed germination (Ayşe et al. 2012). Lipids have been shown to be an important source of energy in the early stages of germination, and lipase activity increases during germination (Kawiński et al. 2021; Vijayakumar and Gowda 2012). Phytases, also found in aleurone, scutellum, and embryo (Guzmán-Ortiz et al. 2019), improve the bioavailability of inorganic phosphate to help in seedlings growth with their temporal expression (Sung et al. 2005). Other enzymes that are activated in the germination process are protein degradation enzymes. Hydrolysis of proteins stored in seeds helps to release free amino acids, and these free amino acids help the biosynthesis of proteins in the endosperm and embryo (Joshi 2018). In this research, the main goal was to perform a GWAS to identify the genomic regions affecting the germination in an international rice population in order to identify candidate genes associated with germination traits.

\section{Results}

\section{Phenotypic variation (PV) in rice accessions}

Most of the traits were almost normally distributed, except for RDW, SDW and RFW showing skewness (Supplementary Fig. 1). We considered the emergence of the radical tip as the beginning of germination. Most of the cultivars reached this stage after $4 d$, but the range was 2-7 d (Table 1), meaning how many seeds are germinated. The broad-sense heritability $\left(\mathrm{h}_{\mathrm{b}}{ }^{2}\right)$ was between 0.465 for RDW to 0.746 for SL (Table 1 ), indicating that most of traits are relatively under the control of environment with a lot of genes being involved in defining the germination in rice.

Table 1

Descriptive statistics of germination traits in a collection of rice pupulation. Standard deviation, minimum and maximum values for germination traits in the Oryza sativa collection are provided.

\begin{tabular}{|lllllllll|}
\hline & NDG & RDW $(\mathbf{m g})$ & SDW $(\mathbf{m g})$ & GP & SL (cm) & RL (cm) & RFW (mg) & SFW (mg) \\
\hline Average & 4 & 0.0040 & 0.0273 & 0.910 & 6.800 & 5.210 & 0.0210 & 0.212 \\
\hline Minimum & 2 & 0.0007 & 0.0040 & 0.230 & 13.800 & 1.030 & 0.0005 & 0.010 \\
\hline Maximum & 7 & 0.0414 & 0.2730 & 0.950 & 1.530 & 12.000 & 0.3033 & 0.440 \\
\hline $\mathrm{H}_{\mathrm{b}}{ }^{2}$ & - & 0.4650 & 0.5340 & - & 0.746 & 0.632 & 0.6150 & 0.497 \\
\hline $\mathrm{SD}$ & 1.507 & 0.0050 & 0.0380 & 0.116 & 2.055 & 2.345 & 0.0440 & 0.075 \\
\hline
\end{tabular}

\section{Population stratification, LD levels and GWAS}

The kinship matrix summarized the distribution of the pairwise relative relationship coefficients among the accessions in the association panel based on SNPs information (Fig. 1a). The results showed relatively higher genetic relatedness within populations. All twelve rice chromosomes showed a significant and very slow LD decay; as were dropped to 0.2 in around $400 \mathrm{~kb}$ (nearly $2 \mathrm{cM}$ ) and to 0.1 in around $1.2 \mathrm{Mbp}$ (more than $5 \mathrm{cM}$ ) (Fig. 1b). Our data were consistent with an earlier result obtained in rice (Mather et al. 2007). Scree plot from GAPIT showed the selection of PCs, representative of population structure, for association study in three main groups (Fig. 1c). The 


\section{Marker-trait association (MTA) analysis}

In order to identify genetic loci responsible for variation in germination traits in rice accessions, GWAS was carried out on a high-quality SNP array. The Manhattan and Q-Q plots for germination traits are shown in Fig. 2 and supplementary Fig. 2 respectively. Markers with $-\log _{10}(P)>3$ were considered as significant markers for NDG, RDW, $\mathrm{SL}$, and SFW. For SDW, RL, and RFW, markers with - $\log 10(P)>4$ were considered as significant. Markers with $\log 10(P)>10$ were considered as significant markers for GP. The MLM model identified a total of 70 significant marker-trait associations (Table 2). For NDG, five genomic regions (a total of 11 SNP markers) were identified on chromosomes 1, 2, 6, 8, 12, demonstrating 5.0-6.23\% of the PV. For RDW, three genomic regions tagged by five SNP markers were identified on chromosomes 4,7 and 8 with $6.65-8.03 \%$ of the PV. For SDW, four genomic regions tagged to seven SNP markers on chromosomes 2, 3, 7 and 8 were identified. The PV for SDW was between 7.4$18.7 \%$. For GP, five genomic regions tagged by 15 SNP markers were identified that explained $22.38-58.0 \%$ of the PV. These regions were on chromosomes 1, 2, 4, 7, and 12. For SL, five significant SNP markers identified in 2 genomic regions (chromosomes 7 and 12), which explained between 6.62-7.38\% of the PV. For RL, five SNPs tagged in 2 genomic regions (chromosomes 8 and 12) were identified that explained $7.46-9.11 \%$ of the PV. For RFW, 12 SNPs in 4 genomic regions located on chromosomes 1, 2, 6 and 8 were identified with a PV of 7.52-18.66\%. For SFW, eight SNPs were found on chromosomes 1 and 6 with a PV of 5.46-7.45\% (Table 2). The physical locations of the markers and the genes are shown in Fig. 3. 
Table 2

SNPs-association with NDG, RDW, SDW, GP, SL, RL, RFW, and SFW.

\begin{tabular}{|c|c|c|c|c|c|c|c|}
\hline Trait & Marker & Chr. & $\mathrm{R}^{2}$ & $\operatorname{fog}_{10} P$-value & $\begin{array}{l}\text { Position } \\
\text { (MBP) }\end{array}$ & $\begin{array}{l}\text { No. of } \\
\text { significant } \\
\text { SNPs in } \\
\text { QTL } \\
\text { regions }\end{array}$ & $\begin{array}{l}\text { Associated genes to } \\
\text { SNP marker }\end{array}$ \\
\hline \multirow[t]{5}{*}{ NDG } & id12001382 & 12 & 5.46 & 3.79 & $\begin{array}{l}3407246 \pm \\
50\end{array}$ & 1 & $\begin{array}{l}\text { LOC_Os } 12 \mathrm{~g} 07110 \text { (acyl- } \\
\text { CoA synthetase) }\end{array}$ \\
\hline & id8001343 & 8 & 5.46 & 3.24 & $\begin{array}{l}4081390 \pm \\
50\end{array}$ & 3 & $\begin{array}{l}\text { LOC_Os08g07270 (O- } \\
\text { glucosyltransferase 2), } \\
\text { LOC_Os08g07290 } \\
\text { (HEAT protein), } \\
\text { LOC_Os08g07300 } \\
\text { (haloacid dehalogenase } \\
\text { 3) }\end{array}$ \\
\hline & id1009883 & 1 & 6.23 & 3.16 & $\begin{array}{l}14857164 \pm \\
50\end{array}$ & 2 & $\begin{array}{l}\text { LOC_Os01g26210 } \\
\text { (OsWAK6), } \\
\text { LOC_Os01g26160 } \\
\text { (Exportin 1) }\end{array}$ \\
\hline & id6010296 & 6 & 5.40 & 3.14 & $\begin{array}{l}19454974 \pm \\
50\end{array}$ & 1 & $\begin{array}{l}\text { LOC_Os06g33320 (G- } \\
\text { protein) }\end{array}$ \\
\hline & id2016360 & 2 & 5.00 & 3.14 & $\begin{array}{l}35519431 \pm \\
50\end{array}$ & 4 & $\begin{array}{l}\text { LOC_Os02g58020 (ABC } \\
\text { transporter), } \\
\text { LOC_Os02g57940 } \\
\text { (OsFBX74), } \\
\text { LOC_Os02g57960 } \\
\text { (Leucine Rich protein), } \\
\text { LOC_Os02g58080 } \\
\text { (SUT4) }\end{array}$ \\
\hline \multirow[t]{5}{*}{ RDW } & id8007379 & 8 & 8.03 & 4.21 & $\begin{array}{l}27025397 \pm \\
50\end{array}$ & 1 & $\begin{array}{l}\text { LOC_Os08g42720 } \\
\text { (solute carrier family 35) }\end{array}$ \\
\hline & id4010508 & 4 & 6.56 & 3.64 & $\begin{array}{l}31004419 \pm \\
50\end{array}$ & 1 & $\begin{array}{l}\text { LOC_Os04g52250 } \\
\text { (Protease inhibitor/seed } \\
\text { storage/ Itp family) }\end{array}$ \\
\hline & id8006888 & 8 & 6.52 & 3.56 & $\begin{array}{l}24882466 \pm \\
50\end{array}$ & 1 & $\begin{array}{l}\text { LOC_Os08g39370 } \\
\text { (citrate transporter) }\end{array}$ \\
\hline & wd7001684 & 7 & 6.86 & 3.43 & $\begin{array}{l}12533004 \pm \\
50\end{array}$ & 1 & $\begin{array}{l}\text { LOC_Os07g22350 } \\
\text { (glucose-6-phosphate 1- } \\
\text { dehydrogenase) }\end{array}$ \\
\hline & id8007277 & 8 & 6.65 & 3.41 & $\begin{array}{l}26539291 \pm \\
50\end{array}$ & 1 & $\begin{array}{l}\text { LOC_Os08g42010 } \\
\text { (nodulin) }\end{array}$ \\
\hline \multirow[t]{2}{*}{ SDW } & id3017683 & 3 & 18.70 & 8 & $\begin{array}{l}35509733 \pm \\
50\end{array}$ & 1 & $\begin{array}{l}\text { LOC_Os03g62860 } \\
\text { (glucan endo-1,3-beta- } \\
\text { glucosidase) }\end{array}$ \\
\hline & id2014670 & 2 & 8.38 & 4.17 & $\begin{array}{l}32979137 \pm \\
50\end{array}$ & 3 & $\begin{array}{l}\text { LOC_Os02g53820 } \\
\text { (endoglucanase), } \\
\text { LOC_Os02g54010(lipase } \\
\text { 3), LOC_Os02g54030 } \\
\text { (polygalacturonase) }\end{array}$ \\
\hline
\end{tabular}




\begin{tabular}{|c|c|c|c|c|c|c|c|}
\hline Trait & Marker & Chr. & $\mathrm{R}^{2}$ & $\log _{10} P$-value & $\begin{array}{l}\text { Position } \\
\text { (MBP) }\end{array}$ & $\begin{array}{l}\text { No. of } \\
\text { significant } \\
\text { SNPs in } \\
\text { QTL } \\
\text { regions }\end{array}$ & $\begin{array}{l}\text { Associated genes to } \\
\text { SNP marker }\end{array}$ \\
\hline & id7005737 & 7 & 9.27 & 4.13 & $\begin{array}{l}28557782 \pm \\
50\end{array}$ & 1 & $\begin{array}{l}\text { LOC_Os07g47820 (acyl- } \\
\text { CoA dehydrogenase 10) }\end{array}$ \\
\hline & ud8000043 & 8 & 7.70 & 4.12 & $580911 \pm 50$ & 1 & $\begin{array}{l}\text { LOC_Os08g01940 (non- } \\
\text { lysosomal } \\
\text { glucosylceramidase) }\end{array}$ \\
\hline & id8000288 & 8 & 7.40 & 4 & $706101 \pm 50$ & 1 & $\begin{array}{l}\text { LOC_Os08g02094 } \\
\text { (lipase/acyl hydrolase) }\end{array}$ \\
\hline \multirow[t]{9}{*}{ GP } & wd1001610 & 1 & 58.00 & 21.23 & $\begin{array}{l}21440232 \pm \\
50\end{array}$ & 1 & $\begin{array}{l}\text { LOC_Os01g38229 } \\
\text { (peptidyl-prolyl } \\
\text { isomerase) }\end{array}$ \\
\hline & ud7000240 & 7 & 40.90 & 16.5 & $\begin{array}{l}3358568 \pm \\
50\end{array}$ & 1 & $\begin{array}{l}\text { LOC_Os07g06860 } \\
\text { (gibberellin receptor } \\
\text { GID1L2) }\end{array}$ \\
\hline & id7003209 & 7 & 36.35 & 15.45 & $\begin{array}{l}20393040 \pm \\
50\end{array}$ & 3 & $\begin{array}{l}\text { LOC_Os07g34190 } \\
\text { (Stilbene and chalcone } \\
\text { synthases), } \\
\text { LOC_Os07g34140 } \\
\text { (chalcone synthase), } \\
\text { LOC_Os07g34110 } \\
\text { (DUF6) }\end{array}$ \\
\hline & id4006430 & 4 & 33.1 & 14.26 & $\begin{array}{l}20380040 \pm \\
50\end{array}$ & 3 & $\begin{array}{l}\text { LOC_Os04g33590 } \\
\text { (hydrolase, alpha/beta } \\
\text { fold family protein), } \\
\text { LOC_Os04g33640 } \\
\text { (glycosyl hydrolases } \\
\text { family 17), } \\
\text { LOC_Os04g33720 } \\
\text { (glycosyl hydrolases) }\end{array}$ \\
\hline & id1007796 & 1 & 25.36 & 11.43 & $\begin{array}{l}10825444 \pm \\
50\end{array}$ & 2 & $\begin{array}{l}\text { LOC_Os01g19170 } \\
\text { (polygalacturonase), } \\
\text { LOC_Os01g19220 (beta- } \\
\text { D-xylosidase) }\end{array}$ \\
\hline & wd1000531 & 1 & 25.36 & 11.42 & $\begin{array}{l}10713826 \pm \\
50\end{array}$ & 1 & $\begin{array}{l}\text { LOC_Os01g18950 } \\
\text { (peroxidase) }\end{array}$ \\
\hline & id12006484 & 12 & 25.24 & 11.19 & $\begin{array}{l}19320321 \pm \\
50\end{array}$ & 1 & $\begin{array}{l}\text { LOC_Os12g32250 } \\
\text { (WRKY96) }\end{array}$ \\
\hline & id7000519 & 7 & 24.88 & 10.62 & $\begin{array}{l}3649192 \pm \\
50\end{array}$ & 2 & $\begin{array}{l}\text { LOC_Os07g07320 } \\
\text { (glutathione S- } \\
\text { transferase), } \\
\text { LOC_Os07g07340 } \\
\text { (glucan endo-1,3-beta- } \\
\text { glucosidase) }\end{array}$ \\
\hline & id2001900 & 2 & 22.38 & 10.27 & $\begin{array}{l}3404588 \pm \\
50\end{array}$ & 1 & $\begin{array}{l}\text { LOC_Os02g06840 } \\
\text { (galactosyltransferase) }\end{array}$ \\
\hline
\end{tabular}




\begin{tabular}{|c|c|c|c|c|c|c|c|}
\hline Trait & Marker & Chr. & $\mathrm{R}^{2}$ & tog $_{10} P$-value & $\begin{array}{l}\text { Position } \\
\text { (MBP) }\end{array}$ & $\begin{array}{l}\text { No. of } \\
\text { significant } \\
\text { SNPs in } \\
\text { QTL } \\
\text { regions }\end{array}$ & $\begin{array}{l}\text { Associated genes to } \\
\text { SNP marker }\end{array}$ \\
\hline \multirow[t]{5}{*}{ SL } & id12001349 & 12 & 7.88 & 4.29 & $\begin{array}{l}3280034 \pm \\
50\end{array}$ & 2 & $\begin{array}{l}\text { LOC_Os12g06800 } \\
\text { (serine esterase), } \\
\text { LOC_Os12g06810 (WD } \\
\text { domain 48) }\end{array}$ \\
\hline & id12001382 & 12 & 6.97 & 3.88 & $\begin{array}{l}3407246 \pm \\
50\end{array}$ & 1 & $\begin{array}{l}\text { LOC_Os12g07110 (acyl- } \\
\text { CoA synthetase) }\end{array}$ \\
\hline & id7001911 & 7 & 8.86 & 3.76 & $\begin{array}{l}10811204 \pm \\
50\end{array}$ & 2 & $\begin{array}{l}\text { LOC_Os07g18240 } \\
\text { (lectin-like receptor } \\
\text { kinase), } \\
\text { LOC_Os07g18120 } \\
\text { (aldehyde oxidase) }\end{array}$ \\
\hline & id7002230 & 7 & 6.62 & 3.73 & $\begin{array}{l}13595959 \pm \\
50\end{array}$ & 1 & $\begin{array}{l}\text { LOC_Os07g23944 } \\
\text { (GH31) }\end{array}$ \\
\hline & wd7001684 & 7 & 7.38 & 3.58 & $\begin{array}{l}12533004 \pm \\
50\end{array}$ & 1 & $\begin{array}{l}\text { LOC_Os07g22350 } \\
\text { (glucose-6-phosphate 1- } \\
\text { dehydrogenase) }\end{array}$ \\
\hline \multirow[t]{2}{*}{ RL } & id12001349 & 12 & 7.46 & 4.24 & $\begin{array}{l}3280034 \pm \\
50\end{array}$ & 2 & $\begin{array}{l}\text { LOC_Os12g06800 } \\
\text { (serine esterase), } \\
\text { LOC_Os12g06810 (WD } \\
\text { domain 48) }\end{array}$ \\
\hline & id8007314 & 8 & 9.11 & 4 & $\begin{array}{l}26837234 \pm \\
50\end{array}$ & 3 & $\begin{array}{l}\text { LOC_Os08g42550 (AP2 } \\
\text { protein), } \\
\text { LOC_Os08g42410 } \\
\text { (transketolase), } \\
\text { LOC_Os08g42450 } \\
\text { (Annexin A7) }\end{array}$ \\
\hline \multirow[t]{4}{*}{ RFW } & id1011623 & 1 & 18.66 & 8.25 & $\begin{array}{l}19509449 \pm \\
50\end{array}$ & 2 & $\begin{array}{l}\text { LOC_Os01g35230 (L- } \\
\text { aminocyclopropane-L- } \\
\text { carboxylate oxidase), } \\
\text { LOC_Os01g35160 } \\
\text { (DUF26) }\end{array}$ \\
\hline & id1023217 & 1 & 12.29 & 6.16 & $\begin{array}{l}36606107 \pm \\
50\end{array}$ & 2 & $\begin{array}{l}\text { LOC_Os01g63160 (MYB } \\
\text { family transcription } \\
\text { factor), } \\
\text { LOC_Os01g63180 } \\
\text { (laccase-6) }\end{array}$ \\
\hline & id6012421 & 6 & 9.83 & 4.98 & $\begin{array}{l}23912891 \pm \\
50\end{array}$ & 1 & $\begin{array}{l}\text { LOC_Os06g40170 } \\
\text { (phospholipase D) }\end{array}$ \\
\hline & id6015037 & 6 & 8.74 & 4.65 & $\begin{array}{l}26809019 \pm \\
50\end{array}$ & 2 & $\begin{array}{l}\text { LOC_Os06g44370 (WD } \\
\text { domain), } \\
\text { LOC_Os06g44460 (D-3- } \\
\text { phosphoglycerate } \\
\text { dehydrogenase) }\end{array}$ \\
\hline
\end{tabular}




\begin{tabular}{|c|c|c|c|c|c|c|c|}
\hline Trait & Marker & Chr. & $\mathrm{R}^{2}$ & $\log _{10} P$-value & $\begin{array}{l}\text { Position } \\
\text { (MBP) }\end{array}$ & $\begin{array}{l}\text { No. of } \\
\text { significant } \\
\text { SNPs in } \\
\text { QTL } \\
\text { regions }\end{array}$ & $\begin{array}{l}\text { Associated genes to } \\
\text { SNP marker }\end{array}$ \\
\hline & id8007573 & 8 & 8.36 & 4.46 & $\begin{array}{l}27592676 \pm \\
50\end{array}$ & 3 & $\begin{array}{l}\text { LOC_Os08g43700 } \\
\text { (Auxin-responsive } \\
\text { SAUR), } \\
\text { LOC_Os08g43570 (beta- } \\
\text { galactosidase), } \\
\text { LOC_Os08g43560 } \\
\text { (Ascorbate Peroxidase) }\end{array}$ \\
\hline & id8004844 & 8 & 7.52 & 4.08 & $\begin{array}{l}18343102 \pm \\
50\end{array}$ & 1 & $\begin{array}{l}\text { LOC_Os08g29770 } \\
\text { (endoglucanase) }\end{array}$ \\
\hline & id2006290 & 2 & 10.31 & 4.07 & $\begin{array}{l}15705734 \pm \\
50\end{array}$ & 1 & $\begin{array}{l}\text { LOC_Os02g26814 (UDP- } \\
\text { N-acetylglucosamine } \\
\text { transferase subunit } \\
\text { ALG13) }\end{array}$ \\
\hline \multirow[t]{5}{*}{ SFW } & id1013001 & 1 & 7.45 & 3.73 & $\begin{array}{l}22806870 \pm \\
50\end{array}$ & 1 & $\begin{array}{l}\text { LOC_Os01g40430 } \\
\text { (WRKY27) }\end{array}$ \\
\hline & id1026302 & 1 & 5.90 & 3.32 & $\begin{array}{l}41101759 \pm \\
50\end{array}$ & 2 & $\begin{array}{l}\text { LOC_Os01g71000 } \\
\text { (protein kinase APK1B), } \\
\text { LOC_Os01g71010 } \\
\text { (lipase) }\end{array}$ \\
\hline & wd6000411 & 6 & 6.15 & 3.08 & $\begin{array}{l}8871246 \pm \\
50\end{array}$ & 1 & $\begin{array}{l}\text { LOC_Os06g15620 } \\
\text { (GASR7) }\end{array}$ \\
\hline & id6016397 & 6 & 5.46 & 3.03 & $\begin{array}{l}28799533 \pm \\
50\end{array}$ & 3 & $\begin{array}{l}\text { LOC_Os06g47620 } \\
\text { (peptidase), } \\
\text { LOC_Os06g47700 } \\
\text { (serine/threonine-protein } \\
\text { kinase BRI1-like 2), } \\
\text { LOC_Os06g47640 } \\
\text { (Calmodulin-related } \\
\text { calcium sensor protein } \\
\text { 29) }\end{array}$ \\
\hline & id6005326 & 6 & 5.46 & 3.03 & $\begin{array}{l}8186912 \pm \\
50\end{array}$ & 1 & $\begin{array}{l}\text { LOC_Os06g14630 } \\
\text { (GDSL-like lipase/acyl } \\
\text { hydrolase) }\end{array}$ \\
\hline
\end{tabular}

The results showed that the marker id12001382 that corresponds to the acyl-CoA synthetase gene was a common marker between SL and NDG. The marker wd7001684 corresponds to glucose-6-phosphate 1-dehydrogenase gene was a common candidate gene for SL and RDW and the marker id12001349 that corresponds to serine esterase and LWD domain 48 was a common candidate gene for SL and RL (Table 2).

\section{Discussion}

Unlike other grains, rice grain has the ability to germinate under anaerobic and hypoxic conditions (Miro and Ismail 2013), but in early stages of seedling growth, it is extremely sensitive to anaerobic conditions (Facon 2000; Ismail et al. 2009 and 2013). This study presents a comprehensive genetic dissection of germination traits in a rice population resultina in the identification of a total of 70-related QTLS. Loading [MathJax]/jax/output/CommonHTML/fonts/TeX/fontdata.js 


\section{Associated genes with NDG}

In the germination process of each seed, the number of days required for germination is an important issue. Because seeds that do not germinate within a certain period of time may rot or be eaten by macro and microorganisms. GWAS results showed 11 candidate genes, acyl-CoA synthetase, $O$-glucosyltransferase 2, HEAT protein, haloacid dehalogenase 3, OsWAK6, Exportin 1, G-protein, ABC transporter, OsFBX74, leucine rich protein and sucrose transporter SUT4 for NDG (Table 2).

Degradation of fatty acids begins with the activation of acyl-CoAs by the enzyme acyl-CoA synthetase (ACS; Hayashi et al. 2002) that follows with $\beta$-oxidation cycle to decompose acetate units one after the other (Hayashi et al. 2002). In our study, ACS was a common candidate gene between NDG and SL. Earlier, its relevance to germination was established (Fulda et al. 2004; Zhang et al. 2020). O-glucosyltransferase 2 previously was shown to be involved in Arabidopsis seed germination (Zhang et al. 2016). HEAT protein among many other functions (AlWhaibi 2011), have been shown to be involved in the germination of wheat, maize, Arabidopsis, and tomatoes (Helm et al. 1989; Su and Li, 2008; Abreu et al. 2016; Ma et al. 2019). Haloacid dehalogenase 3 has hydrolase activity and its overexpression in rice resulted in enhanced phosphatase activity (Pandey et al. 2017). Phosphorus deficiency has been shown to reduce seed size and number (Silva et al. 2014). On the other hand, larger seeds have the ability to germinate in deep soil layers that gives the plant the ability to be more drought resistant (Yi et al. 2019). A study showed that seeds with more phosphate have faster germination and more seedling growth (Ros et al. 1997). Therefore, this gene is likely to affect germination by interfering with the amount of phosphate in the seed during germination.

Other associated gene was OSWAK6, a receptor-like protein kinase to sense both intra- and extra-cellular signals (de Oliveira et al. 2014). Although no relationship has been established between this protein and germination, due to their involvement in hormone signaling (Li et al. 2017) similar functions are being speculated here. Wang et al. (2010) demonstrated qGR-1, a rice seed vigor QTL, to be located in this chromosomal region. G-protein, the other associated gene to NDG, was shown to be involved in the germination process in crops (Ullah et al. 2002; Pandey et al. 2006; Botto et al. 2009; Ma et al. 2017). Gibberellins, the germination intrinsic factor, is being stimulated by Gprotein family of enzymes (Assmann 2005).

Other associated gene to NDG was an $A B C$ transporter. $A B C$ transporters are essential for plant growth and development and play an important role in processes such as germination, organ formation and organ growth. They are involved in germination by interfering with various cellular processes (Kanai et al. 2010; Basu et al. 2019). For example, they can be negatively involved in the germination process by transferring abscisic acid (Ko et al. 2014). Study by Fedi et al. (2017) showed that mutation in an ABC transporter speeded up the germination. Other candidate gene was OsFBX74 that is part of a large family of proteins in plants, with various roles (Wang et al. 2016; Baute et al. 2017) including germination (Majee et al. 2018. It has been shown that overexpression of OsFBX74 in rice delays germination and increases grain size (Chen et al. 2013). Leucine rich protein, the other associated gene with NDG, are abscisic acid responsive (Finkelstein et al. 2002). The loss-of-function of this gene showed ABA insensitivity and improved seed germination (Osakabe et al. 2005). Sucrose transporter SUT4 was also showed to be associated to NDG as its involvement in germination was reported previously (Siao et al. 2011; Li et al. 2012). Overexpression of this gene has been shown to increase susceptibility to ABA during seed incubation (Wang et al. 2020).

\section{Associated genes with GP}

Loading [MathJax]/jax/output/CommonHTML/fonts/TeX/fontdata.js 
GWAS results showed nine associated markers with 15 genes including peptidyl-prolyl isomerase, gibberellin receptor GID1L2, chalcone synthase, DUF6, hydrolase, alpha/beta fold family protein, glycosyl hydrolases family 17 , glycosyl hydrolases, Polygalacturonase, beta-D-xylosidase, peroxidase, WRKY96, glutathione S-transferase, glucan endo-1,3-beta-glucosidase, galactosyltransferase with GP.

Peptidyl prolyl isomerase was shown to negatively regulate ABA signaling, negative regulator of seed germination, in Arabidopsis (Jung et al. 2020). Gibberellin receptor GID1L2 plays an important role in germination via signal perception of gibberellins (Voegele et al. 2011; Munteanu et al. 2014). Chalcone synthase is a key enzyme involved in the flavonoid biosynthesis pathway in higher plants (Yonekura-Sakakibara et al. 2019). This gene can control the germination of plant seeds (Debeaujon et al. 2000). It has also been shown that this gene could affect seed dormancy by regulating the expression of ABA signaling-related genes (Gao et al. 2018). Therefore, this gene seems to play a role in initiating seed germination.

DUF6 is part of the plant metabolite transporter family. DUF6 was introduced for germinating ability for cold (Borjas et al. 2016) and salt tolerance (Zeng et al. 2020). The other associated marker to PG was id4006430 on chromosome 4 that corresponds to a gene cluster containing three hydrolytic enzyme (GH17) encoding genes (Mindrebo et al. 2016). Glycosyl hydrolysing enzymes are the prerequisite for seed germination (Minic and Jouanin 2006; Ferreira et al. 2009). The marker is co-localised with qHD4 and qGI1 markers, which have been introduced as a germination-related gene (Wang et al. 2010; Fujino et al. 2015). The next associated gene with PG was a polygalacturonase with demonstrated function in seed germination in rice and Arabidopsis (Chen et al. 2019). The role of peroxidase, the other associated gene with PG, with germination process has already been determined (Lakra et al. 2019; Mousavizadeh et al. 2013; Bellani et al. 2002). Another associated gene was WRKY96, a transcription factor family with demonstrated role in seed germination and plant development (Han et al. 2020). The marker id7000519 on chromosome 7 corresponds to a gene cluster containing glutathione $S$-transferase and glucan endo1,3- $\beta$-glucosidase. This marker is co-localised with the qAG3 marker, a germination-related marker (Baltazar et al. 2019). Over expression of glutathione Stransferase in rice (Takesawa et al. 2002) and Arabidopsis (Kumar and Trivedi, 2018) showed enhancement of germination rate that led to early bolting (Kumar et al. 2015).

\section{Associated genes with RDW}

Root and seedling dry matter can be defined as seed reserve mobilization efficiency. The result of GWAS showed five associated genes including solute carrier family 35, Protease inhibitor/seed storage/LTP family, citrate transporter, glucose-6-phosphate 1-dehydrogenase and nodulin with RDW. Solute carrier protein is responsible for solute transfer across biological membranes, including inorganic ions, amino acids, lipids, sugars (Bai et al. 2017). The role of these proteins in germination has not yet been established. However, due to the metabolism that occurs during germination, many carriers are likely to be activated in this process. During germination, seed proteins are broken down by proteases to produce nitrogen for the biosynthesis of other substances (Martinez et al. 2019). It has been shown that protease inhibitor activities such as protease inhibitor/seed storage/LTP family decreases during the germination process (Pagnussat et al. 2015). Other associated gene was a nodulin with possible function in germination in Arabidopsis (Denancé et al. 2014).

\section{Associated genes with SDW}

GWAS found seven associated genes with SDW, interestingly all of which were hydrolytic enzymes for carbohydrates and lipids. Glucan endo-1,3- $\beta$-glucosidase, a cell wall degradative enzyme, has been shown to be involved in germination (Leubner-Metzger, 2003). Endoglucanase, an enzyme that randomly hydrolyse $\beta-1,4-g l u c a n$

Loading [MathJax]/jax/output/CommonHTML/fonts/TeX/fontdata.js bciated gene. The wall needs to be loosened up during 
germination and endoglucanase can efficiently contribute in this process. Polygalacturonase with role in germination (Hu et al. 2017; Chen et al. 2019) was the other associated gene with SDW. Lipase 3 showed association with SDW in GWAS. During seed germination, stored lipids are expected to be broken down and to be used as an energy resource for root and seedling production (Penfield et al. 2005; Graham 2008). Acyl-CoA dehydrogenase 10 (ACADs), key enzymes in fatty acid and amino acid catabolism (Shen et al. 2009), was found to be associated with SDW. The activity of this enzyme in cotyledon tissue has been determined during germination (Masterson et al. 2000). Other associated gene with SDW was non-lysosomal glucosylceramidase that catalyses glucosylceramide to glucose and ceramide (Boot et al. 2007). It has been shown this hydrolytic enzyme increase its activity during germination (Guzmán-Ortiz et al. 2019).

\section{Associated genes with SL}

Our GWAS results showed five associated genes with SL. First candidate marker was id12001349 that corresponds to two candidate genes, serine esterase and WD domain 48 that are common genes with root length. Lectin-like receptor kinase, negative regulator of ABA during germination (Deng et al. 2009; Chen et al. 2013; Sun et al. 2013), was the other associated gene with SL. In another GWAS in maize, its role as a chilling tolerant gene was established (Hu et al. 2017). Aldehyde oxidase, an enzyme that catalyses the final step of ABA biosynthesis (Seo et al. 2000), was the other associated gene with SL. An a-glucosidases (GH31) with starch hydrolysis activity (Rozeboom et al. 2013) was also found in our GWAS. A glucose-6-phosphate 1-dehydrogenase was the other associated gene with SL. Its involvement in Arabidopsis germination has been previously reported (Yang ${ }^{\mathrm{b}}$ et al. 2019).

\section{Associated genes with RL}

Root length is an important factor in cereals germination (Hammer et al. 2009). It contributes to the germination via nutrient and water uptake and helps plant to become stabile in soil (Lilley and Kirkegaard 2007). Our results showed five associated genes for RL: a serine esterase, WD domain 48, AP2 protein, transketolase, and annexin A7. Serine esterase has been shown to be involved in Arabidopsis germination (Huang et al. 2015). WD domain 48 was reported to be involved in Arabidopsis germination inhibition (Chuang et al. 2015). AP2 transcription factor, among many other developmental functions (Sekhwal et al. 2014), have been shown in germination regulation (Yamagishi et al. 2009). Transketolase, a restriction enzyme in the pentose phosphate pathway, was showed to be associated with RL here and by Jiang et al. (2017) as qGRR11 QTL. Transketolase and ribose phosphate isomerase increase immediately after the onset of germination (Rajjou et al. 2006). Last candidate gene corresponded to root length is Annexin A7 was the other physically associated gene with RL. Annexins are expressed during germination and in the early stages of seedling growth (Cantero et al. 2006; Yan et al. 2016; He et al. 2019).

\section{Associated genes with RFW}

GWAS results showed 12 physically associated genes to RFW. The first one was 1-aminocyclopropane-1-

carboxylate oxidase, an enzyme involved in ethylene biosynthesis. Ethylene, as a hormone, involves in many cellular processes such as germination, seed dormancy, and seedling formation (Corbineau et al. 2014; Wilson et al. 2014). DUF26, the other associated gene with RFW, is a cysteine-containing protein with varieties of functions in various cellular processes (Vaattovaara et al. 2019). Knocking down of this gene in rice has been shown to result in seed germination in an $\mathrm{NaCl}$-containing medium (Zhang et al. 2009). MYB family of transcription factors (TFs) with roles in hormonal signal transduction (Zhang et al. 2018) was the other associated gene with RFW. In Arabidopsis it has been shown that MYBs are involved in the germination process in response to ABA as a positive regulator (Roy 
drought stress (Zhao et al. 2019). Recently, rice qCAD-2-2 QTL (MYB factor) was reported to be involved in anaerobic germination tolerance (Yang ${ }^{a}$ et al. 2019). Other RFW-associated gene was laccase-6. This gene is involved in lignin degradation and detoxification of lignin-derived products. The seed coat of many species contains hydrophobic lignins and husk lignin decomposition may be required for germination. Phospholipase D (PLD) was physically associated with RFW. The nezyme breaks phosphodiester bonds between glycerophospholipids and thus phosphatidic acid is released as an energy source for germination (McDermott 2004; Parthibane et al. 2012). A rice GWAS showed its involvement in germination (Li et al. 2007).

D-3-phosphoglycerate dehydrogenase, a plant gene responsible for serine biosynthesis (Okamura and Hirai, 2017), showed a physical association with RFW. The gene has been proposed to be related to carbohydrate metabolism during germination in Morus notabilis and Nelumbo nucifera (Zaynab et al. 2018). Auxin-responsive SAUR, a negative auxin synthesis and transport regulator (Kant and Rothstein 2009) and positive gibberellic acid regulator (Ren and Gray 2015), showed to be associated with RFW. Loss-of-function of auxin synthesis in Arabidopsis has been shown to delay seed germination (Hussain et al. 2020). Other associated gene with RFW was $\beta$-galactosidase. As reported earlier, corresponding enzyme activity will increase during germination in rice (Oryza sativa L.) (Chantarangsee et al. 2007) to possibly change cell wall structure for better expansion upon cellular divisions (Ramos and Malcata, 2011). Ascorbate peroxidase, a reactive oxygen species scavenging enzyme (Ozyigit et al. 2016) showed to be associated with RFW. In tobacco, overexpression of the corresponding gene has been shown to improve germination under drought stress (Faize et al. 2015). Our results showed the association of endoglucanase to RFW. During germination, the activity of degrading enzymes such as endoglucanases occurs to soften the micropylar region so that radicle emergence becomes possible (Leubner-Metzger and Meins 2000). Other candidate gene was UDP-N-acetylglucosamine transferase subunit ALG13 with synthetic function of lipid-bound oligosaccharides (Sonkar et al. 2017). It has been shown that the activity of this enzyme increases during the germination in Arabidopsis (Tatematsu et al. 2008).

\section{Associated genes with SFW}

GWAS results showed eight candidate genes for SFW. WRKY27 is gibberellins-responsive transcription factor (Gu et al. 2019). Here and for the first time we have reported its possible association with SFW and seed germination as gibberellins are intrinsic factors involved in the germination process (Stejskalová et al. 2015). Protein kinase APK1B, the other SFW-associated gene, is required for ABA signaling during germination (Fujii et al. 2007; He et al. 2011). This QTL is co-located with qNGR1 QTL for seed germination under low temperature for rice by Jiang et al. (2017). GASR7, a GA-induced protein (Zhang et al. 2015), was the other SFW associated gene. Peptidases hydrolyse peptides during seed germination (Martinez et al. 2019). In our study a peptidase gene showed to be associated with the marker responsible to SFW. Other candidate gene was a serine/threonine-protein kinase BRI1-like 2. This protein is involved in hormone-mediated signaling pathway and auxin-activated signaling pathway. Auxin is positively related to the germination process (Hussain et al. 2020). This QTL is similar to S1_1910174 QTL for SDW under salinity condition reported by Luo et al. (2020). Other candidate gene was calmodulin-related calcium sensor protein. Calcium plays a key role in the plant's response to environmental stimuli such as biotic and abiotic stresses as well as plant hormones (Pandey et al. 2004). Calmodulin signals are involved in the inhibition of ABA during seed germination and seedling growth (Zhou et al. 2018) and ABA promotes seed dormancy and inhibits seed germination and post-germination growth (Zhou et al. 2018). It seems this gene has negative relationship with germination. GDSL-like lipase/acylhydrolase that shows lipase activity was the other gene to be associated with SFW. Lipase activity and its involvement in the germination process has already been established (Graham 2008).

Loading [MathJax]/jax/output/CommonHTML/fonts/TeX/fontdata.js

Page 12/27 


\section{Conclusion}

The germination process is an initial and important step in the production of agricultural products, especially for rice, which is a crop plant that is grown in flooded lands. Here, the genetic diversity of rice genotypes was put under scrutiny for germination. Our GWAS results identified several likely candidate genes for germination traits that will greatly contribute to our understanding of the genetic complexity underlying the corresponding traits. The associated genes with the germination traits can be generally classified as hydrolytic enzymes and regulatory proteins that can directly or indirectly influence germination.

\section{Methods}

\section{Rice material}

A collection of 283 accessions of rice ( $O$. sativa L.) genotypes from 82 countries (Supplementary file S1) were sown in plots of $2 \times 2 \mathrm{~m}^{2}$ with $25 \mathrm{~cm}$ within rows spacing in Sari Agricultural and Natural Resources University (Northern Iran). Superphosphate triple (180 kg/ha at plowing), urea (100 kg/ha at seedling stage), and potash (80 kg/ha at plowing stage) were given to plants. Grains of panicles from each plant in three biological replicates were collected at full maturity. Accessions were TEJ (Temperate Japonica), IND (Indica), AUS (aus), ARO (Aroaatic), TRJ (Tropical Japonica), and ADMIX subpopulations. Rice seeds may be dormant for up to 80 days after harvest, depending on the variety and wild and traditional rice cultivars have higher degrees of dormancy than modern ones. In order to break dormancy in the seeds, grains were stored for 90 days at $4{ }^{\circ} \mathrm{C}$ and then germination rate was measured. Rice 44.1 K SNPs array was downloaded from the Gramene portal (http://gramene.org) to use genotyping by sequencing data (Zhao et al. 2011). We used 220 rice accessions in this study.

\section{Evaluation of seed germination}

A total of 20 healthy grains of each accession by three biological replicates were surface-sterilized with $10 \%$ sodium hypochlorite solution for $1 \mathrm{~min}$ and washed three times with sterile $\mathrm{dH}_{2} \mathrm{O}$. The seeds were placed in a petri dish with two sheets of wet filter paper. Seeds were germinated under normal conditions at $25 \pm 1^{\circ} \mathrm{C}$ for $14 \mathrm{~d}$ with a $12 \mathrm{~h}$ light/12 $\mathrm{h}$ dark photoperiod. The plates were checked daily to determine number of days to germinate and coleoptile appearance (NDG). The estimated germination percentage (GP = seeds germinated/total seeds $\times 100)$ is a measure of seed viability (Abdel-Haleem and El-Shaieny, 2015). At day $14^{\text {th }}$, five germinated grains were randomly selected from each replicate and root (RL) and shoot (SL) length, fresh weight of shoots (SFW) and roots (RFW) were measured. The shoots (SDW) and roots (RDW) were placed at $60{ }^{\circ} \mathrm{C}$ for $24 \mathrm{~h}$ and the corresponding dry weights were measured. In total, all traits were measured in three biological replications. Statistical distribution of phenotypes as well as correlation between the traits were plotted at R package of programs (https://cran.rproject.org/). Broad-sense heritability $\left(\mathrm{H}_{\mathrm{b}}{ }^{2}\right)$ was estimated by $\mathrm{R}$ rptR package (https://cran.rproject.org/web/packages/rpart/index.html) using phenotypic data.

\section{Population structure, estimation of LD decay in rice genome and GWAS}

Analysis of population structure among all rice accessions was performed by principal components analysis (PCA) in TASSEL v5 (Bradbury et al. 2007). The PCA analysis and plots were generated using the genomic association and prediction integrated tool (GAPIT) (Lipka et al. 2012). The kinship matrix was obtained at TASSEL v5 and heatmap of the kinship matrix was produced at GAPIT (Zhang et al. 2010). 
Genome-wide linkage disequilibrium (LD) analyses were performed in the association panel in order to evaluate the resolution of LD. Pairwise calculations of LD between SNPs were made in TASSEL using $\mathrm{r}^{2}$ with a sliding window of 50 markers. Graphs depicting the decay of LD with physical distance between SNPs were visualized using ggplot2 in $\mathrm{R}$ (Wickham, 2016).

Association analyses were performed using 33,934 SNPs with a minor allele frequency (MAF) above 5\% and obtained phenotypic data using MLM models in TASSEL. Quantile-quantile (Q-Q) plots (observed versus expected $\log _{10} P$-values) were generated by $\mathrm{R}$ software using qqman package with the results obtained from Tassel to determine the model that fits the data best (Chen et al. 2016). The Manhattan plots were drawn with the results obtained from tassel in R software using qqman package (Turner, 2014).

\section{Bioinformatics and gene identification}

In order to identify genes underlying the QTLs of seed germination-related traits that overlapped with the genomic regions (i.e., their associated SNPs), genes deposited on the Rice Annotation Project database (http://rice.plantbiology.msu.edu/) and also IRGSP-1.0 (https://rapdb.dna.affrc.go.jp/) were assessed. All hypothetical genes were ignored in order to put protein coding sequences and transposable elements into prospect for further analyses. We searched for genes in an interval extending $50 \mathrm{~kb}$ in either direction from SNP markers (i.e., a total of $100 \mathrm{~kb}$ since LD decay is very low in rice; Mather et al. 2007) in order to account for map order uncertainty and LD. To ascertain whether candidate genes underlying our QTLs were previously cloned and functionally annotated, a thorough literature search was made for all genes.

\section{Abbreviations}

GWAS: genome-wide association study; LD: linkage disequilibrium; MLM: mixed linear model; PV: Phenotypic variation; SNP: single nucleotide polymorphism; QTL: quantitative trait loci; GP: germination percentage; SL: shoot length; RL: root length; SFW: shoot fresh weight; RFW: root fresh weight; RDW: root dry weight; SDW: shoot dry weight; NDG: number of days to germinate.

\section{Declarations}

\section{Ethical Approval and Consent to participate}

Not applicable as no animal experiments were involved in the entire project.

\section{Consent for publication}

All the authors have given their consent to publish the manuscript.

\section{Availability of supporting data}

All relevant data have been provided as Tables, Figures with in the text and in the following supplementary data.

\section{Competing interests}

The authors declare that they have no competing interests. 
Shahid Beheshti University supported the research.

\section{Authors' Contributions}

Rahele Panahabadi performed experiments, carried out the GWAS analysis and prepared the draft of manuscript. Asadollah Ahmadikhah co-supervised the research, provided all samples used in the project and carried out phenotypic data analysis. Naser Farokhi co-supervised the research carried out phenotypic data analysis. All authors read and approved the final manuscript.

\section{Acknowledgments}

This research was conducted in Biotechnology laboratory, Department of Plant Sciences and Biotechnology, Shahid Beheshti University, Iran. We thank Sari Agricultural Sciences and Natural Resources University, Sari, Iran for providing land for planting rice genotypes. In addition we express grateful thanks to International Rice Research Institute (IRRI) in Philippines for providing the seeds of rice cultivars.

\section{References}

Abdel-Haleem A, El-Shaieny, H. (2015) Seed germination percentage and early seedling establishment of five (Vigna unguiculata L. (Walp) genotypes under salt stress. Pelagia Research Library 5(2): 22-32.

Abreu VM, Silva Neta IC, Von Pinho EVR, Naves GMF, Guimarães RM, Santos HO, Von Pinho RG. (2016) Heatresistant protein expression during germination of maize seeds under water stress. Genetics and Molecular Research 15(3): 1-8.

Almansouri M, Kinet JM, Lutts S. (2001) Effect of salt and osmotic stresses on germination in durum wheat (Triticum durum L.). Plant and Soil 231: 243-254.

Al-Whaibi MH. (2011) Plant heat-shock proteins: a mini review. Journal of King Saud University-Science 23(2): 139150.

Andriotis VM, Rejzek M, Barclay E, Rugen MD, Field RA, Smith AM. (2016) Cell wall degradation is required for normal starch mobilisation in barley endosperm. Scientific Reports 6(1): 1-15.

Assmann SM. (2005) G protein signaling in the regulation of rice seed germination. Science's STKE 2005(310): cm12-cm12.

Ayşe AK, Yücel E, Sezgin AY. (2012) Relationship between seed germination and catalase enzyme activity of Abies taxa from Turkey. Kastamonu Üniversitesi Orman Fakültesi Dergisi 12(3): 185-188.

Bai X, Moraes TF, Reithmeier RA. (2017) Structural biology of solute carrier (SLC) membrane transport proteins. Molecular Membrane Biology 34(1-2): 1-32.

Baltazar MD, Ignacio JCI, Thomson MJ, Ismail AM, Mendioro MS, Septiningsih EM. (2019) QTL mapping for tolerance to anaerobic germination in rice from IR64 and the aus landrace Kharsu 80A. Breeding Science 69(2): 227233.

Basu U, Upadhyaya HD, Srivastava R, Daware A, Malik N, Sharma A, Tripathi S. (2019) ABC transporter-mediated Loading [MathJax]/jax/output/CommonHTML/fonts/TeX/fontdata.js and quality in chickpea. Plant Physiology 180(1): $253-275$. 
Baute J, Polyn S, De Block J, Blomme J, Van Lijsebettens M, Inzé D. (2017) F-box protein FBX92 affects leaf size in Arabidopsis thaliana. Plant and Cell Physiology 58(5): 962-975.

Bellani LM, Guarnieri M, Scialabba A. (2002) Differences in the activity and distribution of peroxidases from three different portions of germinating Brassica oleracea seeds. Physiologia Plantarum 114(1): 102-108.

Boot RG, Verhoek M, Donker-Koopman W, Strijland A, van Marle, J, Overkleeft HS, Wennekes T, Aerts JM. (2007) Identification of the non-lysosomal glucosylceramidase as $\beta$-glucosidase 2. Biological Chemistry 282(2): 13051312.

Borjas AH, De Leon TB, Subudhi PK. (2016) Genetic analysis of germinating ability and seedling vigor under cold stress in US weedy rice. Euphytica 208(2): 251-264.

Botto JF, Ibarra S, Jones AM. (2009) The heterotrimeric G-protein complex modulates light sensitivity in Arabidopsis thaliana seed germination. Photochemistry and Photobiology 85(4): 949-954.

Bradbury PJ, Zhang Z, Kroon DE, Casstevens TM, Ramdoss, Y, Buckler ES. (2007) TASSEL: software for association mapping of complex traits in diverse samples. Bioinformatics 23: 2633-2635.

Cantero A, Barthakur S, Bushart TJ, Chou S, Morgan RO, Fernandez MP, Roux SJ. (2006) Expression profiling of the Arabidopsis annexin gene family during germination, de-etiolation and abiotic stress. Plant Physiology and Biochemistry 44(1): 13-24.

Caspers MP, Lok F, Sinjorgo KM, Van Zeijl MJ, Nielsen KA, Cameron-Mills V. (2001) Synthesis, processing and export of cytoplasmic endo- $\beta-1,4-x y l a n a s e$ from barley aleurone during germination. The Plant Journal 26(2): $191-204$.

Chantarangsee M, Tanthanuch W, Fujimura T, Fry SC, Cairns JK. (2007) Molecular characterization of $\beta$ galactosidases from germinating rice (Oryza sativa). Plant Science 173(2): 118-134.

Chen X, Chen Y, Zhang L, He Z, Huang B, Chen C, Zuo S. (2019) Amino acid substitutions in a polygalacturonase inhibiting protein (OsPGIP2) increases sheath blight resistance in rice. Rice 12(1): 56.

Chen Y, Xu Y, Luo W, Li W, Chen N, Zhang D, Chong K. (2013) The F-box protein OsFBK12 targets OsSAMS1 for degradation and affects pleiotropic phenotypes, including leaf senescence, in rice. Plant Physiology 163(4): 16731685.

Chen Z, Huang H, Ng H.K.T. (2016) Testing for association in case-control genome-wide association studies with shared controls. Statistical Methods in Medical Research 25(2): 954-967.

Chuang HW, Feng, JH, Feng YL, Wei MJ. (2015) An Arabidopsis WDR protein coordinates cellular networks involved in light, stress response and hormone signals. Plant Science 241: 23-31.

Corbineau F, Xia Q, Bailly C, El-Maarouf-Bouteau H. (2014) Ethylene, a key factor in the regulation of seed dormancy. Frontiers in Plant Science 5: 539.

de Oliveira LFV, Christoff AP, de Lima JC, de Ross BCF, Sachetto-Martins G, Margis-Pinheiro M, Margis R. (2014) The Wall-associated Kinase gene family in rice genomes. Plant Science 229, 181-192.

Loading [MathJax]/jax/output/CommonHTML/fonts/TeX/fontdata.js

Page 16/27 
Debeaujon I, Leon-Kloosterziel KM, Koornneef M. (2000) Influence of the testa on seed dormancy, germination and longevity in Arabidopsis. Plant Physiol 122: 403-414.

Denancé N, Szurek B, Noël LD. (2014) Emerging functions of nodulin-like proteins in non-nodulating plant species. Plant and Cell Physiology 55(3): 469-474.

Deng K, Wang Q, Zeng J, Guo X, Zhao X, Tang D, Liu X. (2009) A lectin receptor kinase positively regulates ABA response during seed germination and is involved in salt and osmotic stress response. Journal of Plant Biology 52(6): 493.

Facon T. (2000) Water management in rice in Asia: Some issues for the future. Bridging the Rice Yield gap in the Asia-Pacific Region 178.

Faize M, Nicolás E, Faize L, Díaz-Vivancos P, Burgos L, Hernández JA. (2015) Cytosolic ascorbate peroxidase and $\mathrm{Cu}, \mathrm{Zn}$-superoxide dismutase improve seed germination, plant growth, nutrient uptake and drought tolerance in tobacco. Theoretical and Experimental Plant Physiology 27(3-4): 215-226.

Fedi F, O’Neill CM, Menard G, Trick M, Dechirico S, Corbineau F, Penfield S. (2017) Awake1, an ABC-type transporter, reveals an essential role for suberin in the control of seed dormancy. Plant Physiology 174(1): 276-283.

Ferreira CS, Piedade MTF, Tiné MAS, Rossatto DR, Parolin P, Buckeridge MS. (2009) The role of carbohydrates in seed germination and seedling establishment of Himatanthus sucuuba, an Amazonian tree with populations adapted to flooded and non-flooded conditions. Annals of Botany 104(6): 1111-1119.

Finkelstein RR, Gampala SS, Rock CD. (2002) Abscisic acid signaling in seeds and seedlings. The Plant Cell 14(1): S15-S45.

Fujii H, Verslues PE, Zhu JK. (2007) Identification of two protein kinases required for abscisic acid regulation of seed germination, root growth, and gene expression in Arabidopsis. The Plant Cell 19(2): 485-494.

Fujino K, Obara M, Shimizu T, Koyanagi KO, Ikegaya T. (2015) Genome-wide association mapping focusing on a rice population derived from rice breeding programs in a region. Breeding science 65(5): 403-410.

Fulda M, Schnurr J, Abbadi A, Heinz E. (2004) Peroxisomal Acyl-CoA synthetase activity is essential for seedling development in Arabidopsis thaliana. The Plant Cell 16(2): 394-405.

Gao Y, Liu J, Chen, Y, Tang H, Wang Y, He Y, Yao Y. (2018) Tomato SIAN11 regulates flavonoid biosynthesis and seed dormancy by interaction with bHLH proteins but not with MYB proteins. Horticulture Research, 5(1): 1-18.

Gomez LD, Steele-King CG, Jones L, Foster JM, Vuttipongchaikij S, McQueen-Mason SJ. (2009) Arabinan metabolism during seed development and germination in Arabidopsis. Molecular Plant 2(5): 966-976.

González-Calle V, Barrero-Sicilia C, Carbonero P, Iglesias-Fernández R. (2015). Mannans and endo- $\beta$-mannanases (MAN) in Brachypodium Distachyon: expression profiling and possible role of the BdMAN genes during coleorhizalimited seed germination. J. Exp. Bot 66: 3753-3764.

Graham IA. (2008) Seed storage oil mobilization. Plant Biol 59: 115-142.

Loading [MathJax]/jax/output/CommonHTML/fonts/TeX/fontdata.js 
Grant MM, Briggs DE, Fitchett CS, Stimson E, Deery MJ. (2003) Purification of an Arabinofuranosidase and Two $\beta$ Xylopyranosidases from Germinated Wheat. Journal of the Institute of Brewing 109(1): 8-15.

Gu L, Dou L, Guo Y, Wang H, Li L, Wang C, Yu S. (2019) The WRKY transcription factor GhWRKY27 coordinates the senescence regulatory pathway in upland cotton (Gossypium hirsutum L.). BMC Plant Biology 19(1): 1-14.

Guzmán-Ortiz F A, Castro-Rosas J, Gómez-Aldapa CA, Mora-Escobedo R, Rojas-León A, Rodríguez-Marín ML, Román-Gutiérrez AD. (2019) Enzyme activity during germination of different cereals: A review. Food Reviews International 35(3): 177-200.

Ha TT, Duong TPL, Phan TBT, Trang ST. (2018) Changes in a-galactosidase activity and oligosaccharides during germination of soybean seeds. Can Tho University Journal of Science 54: 8-15.

Hammer GL, Dong Z, McLean G, Doherty A, Messina C, Schussler J, Cooper M. (2009) Can changes in canopy and/or root system architecture explain historical maize yield trends in the US corn belt?. Crop Science 49(1): 299312.

Han Z, Wang B, Tian L, Wang S, Zhang J, Guo S, Zhang H, Xu L, Chen Y. (2020) Comprehensive dynamic transcriptome analysis at two seed germination stages in maize (Zea mays L.). Physiol. Plant 168: 205-217.

Hayashi H, De Bellis L, Hayashi Y, Nito K, Kato A, Hayashi M, Nishimura M. (2002) Molecular characterization of an Arabidopsis acyl-coenzyme a synthetase localized on glyoxysomal membranes. Plant Physiology 130(4): 20192026.

He D, Han C, Yao J, Shen S, Yang P. (2011). Constructing the metabolic and regulatory pathways in germinating rice seeds through proteomic approach. Proteomics 11(13): 2693-2713.

He F, Gao C, Guo G, Liu J, Gao Y, Pan R, Hu J. (2019) Maize annexin genes ZmANN33 and ZmANN35 encode proteins that function in cell membrane recovery during seed germination. Experimental Botany 70(4): 1183-1195.

Helm KW, Petersen NS, Abernethy RH. (1989) Heat shock response of germinating embryos of wheat: effects of imbibition time and seed vigor. Plant Physiology 90(2): 598-605.

Hu G, Li Z, Lu Y, Li C, Gong S, Yan S, Li G, Wang M, Ren H, Guan H, Zhang Z, Qin D, Chai M, Yu J, Yang D, Wang T, Zhang Z. (2017). Genome-wide association study identified multiple genetic loci on chilling resistance during germination in maize. Scientific Reports 7(1): 1-11.

Huang LM, Lai CP, Chen LFO, Chan MT, Shaw JF. (2015) Arabidopsis SFAR4 is a novel GDSL-type esterase involved in fatty acid degradation and glucose tolerance. Botanical Studies 56(1): 1-12.

Hussain S, Kim SH, Bahk S, Ali A, Nguyen XC, Yun DJ, Chung WS. (2020). The Auxin Signaling Repressor IAA8 Promotes Seed Germination Through Down-Regulation of $A B / 3$ Transcription in Arabidopsis. Frontiers in Plant Science $17 ; 111$.

Ismail AM, Ella ES, Vergara GV, Mackill DJ. (2009) Mechanisms associated with tolerance to flooding during germination and early seedling growth in rice (Oryza sativa). Annals of Botany 103(2): 197-209.

Ismail AM, Singh US, Singh S, Dar MH, Mackill DJ. (2013). The contribution of submergence-tolerant (Sub1) rice Loading [MathJax]/jax/output/CommonHTML/fonts/TeX/fontdata.js eas in Asia. Field Crops Research 152: 83-93.

Page 18/27 
Jiang N, Shi S, Shi H, Khanzada H, Wassan GM, Zhu C, Peng X, Yu Q, Chen X, He X, Fu J, Hu L, Xu J, Ouyang L, Sun X, Zhou D, He H, Bian J. (2017) Mapping QTL for seed germinability under low temperature using a new high-density genetic map of rice. Frontiers in Plant Science 8: 1223.

Joshi R. (2018) Role of enzymes in seed germination. International Journal of Creative Research Thoughts 6(2): 1481-1485.

Jung H, Jo SH, Park HJ, Lee A, Kim HS, Lee HJ, Cho HS. (2020) Golgi-localized cyclophilin 21 proteins negatively regulate $A B A$ signalling via the peptidyl prolyl isomerase activity during early seedling development. Plant Molecular Biology 102(1-2): 19-38.

Kanai M, Nishimura M, Hayashi M. (2010) A peroxisomal ABC transporter promotes seed germination by inducing pectin degradation under the control of $A B / 5$. The Plant Journal 62(6): 936-947.

Kant S, Rothstein S. (2009) Auxin-responsive SAUR39 gene modulates auxin level in rice. Plant Signaling \& Behavior 4(12): 1174-1175.

Kawiński A, Miklaszewska M, Stelter S, Głąb B, Banaś A. (2021) Lipases of germinating jojoba seeds efficiently hydrolyze triacylglycerols and wax esters and display wax ester-synthesizing activity. BMC Plant Biology 21(1): 113.

Kirkegaard JA, Lilley JM, Howe GN, Graham JM. (2007) Impact of subsoil water use on wheat yield. Agricultural Research 58(4): 303-315.

Ko D, Kang J, Kiba T, Park J, Kojima M, Do J, Martinoia E. (2014) Arabidopsis ABCG 14 is essential for the root-toshoot translocation of cytokinin. National Academy of Sciences 111(19): 7150-7155.

Kumar S, Asif MH, Chakrabarty D, Tripathi RD, Dubey RS, Trivedi PK. (2015) Comprehensive analysis of regulatory elements of the promoters of rice sulfate transporter gene family and functional characterization of OsSul1;1 promoter under different metal stress. Plant Signal. Behav 10: 990843.

Kumar S, Trivedi PK. (2018) Glutathione S-transferases: role in combating abiotic stresses including arsenic detoxification in plants. Frontiers in Plant Science 9: 751.

Lakra N, Kaur C, Singla-Pareek SL, Pareek A (2019) Mapping the 'early salinity response'triggered proteome adaptation in contrasting rice genotypes using iTRAQ approach. Rice 12(1): 1-22.

Leubner-Metzger G, Meins JrF.(2000) Sense transformation reveals a novel role for class I $b$-1,3-glucanase in tobacco seed germination. Plant J. 23:215-221.

Leubner-Metzger G. (2003) Functions and regulation of [beta]-1, 3-glucanases during seed germination, dormancy release and after-ripening. Seed Science Research 13(1): 17.

Li G, Lin F, Xue HW. (2007) Genome-wide analysis of the phospholipase D family in Oryza sativa and functional characterization of PLD 31 in seed germination. Cell Research 17(10): 881-894.

Li K, Yang F, Miao Y, Song CP. (2017) Abscisic acid signaling is involved in regulating the mitogen-activated protein kinase cascade module, AIK1-MKK5-MPK6. Plant Signaling \& Behavior 12(5): e1321188.

Loading [MathJax]/jax/output/CommonHTML/fonts/TeX/fontdata.js

Page 19/27 
Li Y, Li LL, Fan RC, Peng CC, Sun HL, Zhu SY, Zhang DP. (2012) Arabidopsis sucrose transporter SUT4 interacts with cytochrome b5-2 to regulate seed germination in response to sucrose and glucose. Molecular Plant 5(5) 1029-1041.

Lilley JM, Kirkegaard JA. (2008) Seasonal variation in the value of subsoil water to wheat: simulation studies in southern New South Wales. Australian Journal of Agricultural Research 58(12): 1115-1128.

Linkies A, Graeber K, Knight C, Leubner-Metzger G. (2010) The evolution of seeds. New. Phytol 186; 817-831.

Lipka AE, Tian F, Wang QS, Peiffer J, Li M, Bradbury PJ, Gore MA, Buckler ES, Zhang ZW. (2012) GAPIT: genome association and prediction integrated tool. Bioinformatics 28(18): 2397-9.

Luo Z, Szczepanek A, Abdel-Haleem H. (2020) Genome-Wide Association Study (GWAS) Analysis of Camelina Seedling Germination under Salt Stress Condition. Agronomy 10(9): 1444.

Ma W, Guan X, Li J, Pan R, Wang L, Liu F, Chen X. (2019) Mitochondrial small heat shock protein mediates seed germination via thermal sensing. Proceedings of the National Academy of Sciences 116(10): 4716-4721.

Ma Z, Bykova NV, Igamberdiev AU. (2017). Cell signaling mechanisms and metabolic regulation of germination and dormancy in barley seeds. The Crop Journal 5(6): 459-477.

Majee M, Kumar S, Kathare PK, Wu S, Gingerich D, Nayak NR, Dirk LM. (2018) KELCH F-BOX protein positively influences Arabidopsis seed germination by targeting PHYTOCHROME-INTERACTING FACTOR1. Proceedings of the National Academy of Sciences 115(17): E4120-E4129.

Martinez M, Gómez-Cabellos S, Giménez MJ, Barro F, Diaz I, Diaz-Mendoza M. (2019) Plant proteases: from key enzymes in germination to allies for fighting human gluten-related disorders. Frontiers in plant science 10: 721.

Masterson C, Blackburn A, Wood C. (2000) Acyl-CoA dehydrogenase activity in pea cotyledon tissue during germination and initial growth doi: 10.1042/bst0280760.

Mather KA, Caicedo AL, Polato NR, Olsen KM, McCouch S, Purugganan MD. (2007) The extent of linkage disequilibrium in rice (Oryza sativa L.). Genetics 177(4): 2223-2232.

McDermott M. (2004) Wakelam MJ, and Morris AJ. Phospholipase D. Biochem Cell Biol 82: 225-253.

Mindrebo JT, Nartey CM, Seto Y, Burkart MD, Noel JP. (2016) Unveiling the functional diversity of the alpha/beta hydrolase superfamily in the plant kingdom. Current Opinion in Structural Biology 41: 233-246.

Minic Z, Jouanin L. (2006) Plant glycoside hydrolases involved in cell wall polysaccharide degradation. Plant physiology and Biochemistry 44(7-9): 435-449.

Miro B, Ismail AM. (2013) Tolerance of anaerobic conditions caused by flooding during germination and early growth in rice (Oryza sativa L.). Frontiers in Plant Science 4: 269.

Mousavizadeh SJ, Sedaghathoor S, Rahimi A, Mohammadi H. (2013) Germination parameters and peroxidase activity of lettuce seed under stationary magnetic field. Journal of Biosciences 3(4): 199-207.

Mrva K, Wallwork M, Mares DJ. (2006) a-Amylase and programmed cell death in aleurone of ripening wheat araine Fxnerimental Rotanv $57(4) \cdot 877-885$

Loading [MathJax]/jax/output/CommonHTML/fonts/TeX/fontdata.js

Page 20/27 
Munteanu V, Gordeev V, Martea R, Duca M. (2014) Effect of gibberellin cross talk with other phytohormones on cellular growth and mitosis to endoreduplication transition. Int. J. Adv. Res. Biol. Sci 1(6): 136-153.

Nambara E, Okamoto M, Tatematsu K, Yano R, Seo M, Kamiya Y. (2010) Abscisic acid and the control of seed dormancy and germination. Seed Science Research 20(2): 55.

Okamura E, Hirai MY. (2017) Novel regulatory mechanism of serine biosynthesis associated with 3phosphoglycerate dehydrogenase in Arabidopsis thaliana. Scientific Reports 7(1): 1-14.

Osakabe Y, Maruyama K, Seki M, Satou M, Shinozaki K, Yamaguchi-Shinozaki K. (2005) Leucine-rich repeat receptor-likekinase 1 is a key membrane-bound regulator of abscisic acid early signaling in Arabidopsis. The Plant Cell 17(4): 1105-1119.

Ozyigit II, Filiz E, Vatansever R, Kurtoglu KY, Koc I, Öztürk MX, Anjum NA. (2016) Identification and comparative analysis of $\mathrm{H}_{2} \mathrm{O}_{2}$-scavenging enzymes (ascorbate peroxidase and glutathione peroxidase) in selected plants employing bioinformatics approaches. Frontiers in Plant Science 7: 301.

Pagnussat LA, Oyarburo N, Cimmino C, Pinedo ML, De La Canal L. (2015) On the role of a lipid-transfer protein. Arabidopsis Itp3 mutant is compromised in germination and seedling growth. Plant signaling \& behavior 10(12): e1105417.

Pandey BK, Mehra P, Verma L, Bhadouria J, Giri J. (2017) OsHAD1, a haloacid dehalogenase-like apase, enhances phosphate accumulation. Plant Physiology 174(4): 2316-2332.

Pandey GK, Cheong YH, Kim KN, Grant JJ, Li L, Hung W, Luan S. (2004) The calcium sensor calcineurin B-like 9 modulates abscisic acid sensitivity and biosynthesis in Arabidopsis. The Plant Cell 16(7): 1912-1924.

Pandey S, Chen JG, Jones AM, Assmann, SM. (2006). G-protein complex mutants are hypersensitive to abscisic acid regulation of germination and postgermination development. Plant Physiology 141(1), 243-256.

Parthibane V, lyappan R, Vijayakumar A, Venkateshwari V, Rajasekharan R. (2012) Serine/threonine/tyrosine protein kinase phosphorylates oleosin, a regulator of lipid metabolic functions. Plant Physiology 159(1): 95-104.

Penfield S, Graham S, Graham IA. (2005) Storage reserve mobilization in germinating oilseeds. Arabidopsis as a model system 33 (2): 380-383.

Rajjou L, Belghazi M, Huguet R, Robin C, Moreau A, Job C, Job, D. (2006) Proteomic investigation of the effect of salicylic acid on Arabidopsis seed germination and establishment of early defense mechanisms. Plant Physiology 141(3): 910-923.

Ramos OS, Malcata FX. (2011) Food-Grade Enzyme. in : ITQB, Oeiras, Portugal.

Ren H, Gray WM. (2015) SAUR proteins as effectors of hormonal and environmental signals in plant growth. Molecular Plant 8(8): 1153-1164.

Ritchie S, Swanson SJ, Gilroy S. (2000) Physiology of the aleurone layer and starchy endosperm during grain development and early seedling growth: new insights from cell and molecular biology. Seed Science Research 10(3): 193-212.

Loading [MathJax]/jax/output/CommonHTML/fonts/TeX/fontdata.js

Page 21/27 
Ros C, Bell RW, White PF. (1997) Effect of seed phosphorus and soil phosphorus applications on early growth of rice (Oryza sativa L.) cv. IR66. Soil Science and Plant Nutrition 43(3): 499-509.

Roy S. (2016) Function of $M Y B$ domain transcription factors in abiotic stress and epigenetic control of stress response in plant genome. Plant Signaling \& Behavior 11(1): 1117723.

Rozeboom HJ, Yu S, Madrid S, Kalk KH, Zhang R, Dijkstra BW. (2013) Crystal structure of a-1, 4-glucan lyase, a unique glycoside hydrolase family member with a novel catalytic mechanism. Biological Chemistry 288(37): 2676426774.

Sekhwal MK, Swami AK, Sharma V, Sarin R. (2014) Identification of drought-induced transcription factors in Sorghum Bicolor using GO term semantic similarity. Cellular \& Molecular Biology Letters 1-23.

Seo M, Peeters AJ, Koiwai H, Oritani T, Marion-Poll A, Zeevaart JA, Koshiba T. (2000) The Arabidopsis aldehyde oxidase $3(A A O 3)$ gene product catalyzes the final step in abscisic acid biosynthesis in leaves. Proceedings of the National Academy of Sciences 97(23): 12908-12913.

Shen YQ, Lang BF, Burger G. (2009) Diversity and dispersal of a ubiquitous protein family: acyl-CoA dehydrogenases. Nucleic Acids Research 37(17): 5619-5631.

Siao W, Chen JY, Hsiao HH, Chung P, Wang SJ. (2011) Characterization of OsSUT2 expression and regulation in germinating embryos of rice seeds. Rice 4(2): 39-49.

Silva DAD, Esteves JADF, Messias U, Teixeira A. Gonçalves JGR, Chiorato AF, Carbonell SAM. (2014). Efficiency in the use of phosphorus by common bean genotypes. Scientia Agricola 71(3): 232-239.

Sonkar A, Shukla H, Shukla R, Kalita J, Pandey T, Tripathi, T. (2017) UDP-N-Acetylglucosamine enolpyruvyl transferase (MurA) of Acinetobacter Baumannii (AbMurA): Structural and functional properties. Biological Macromolecules 97: 106-114.

Stejskalová J, Kupka I, Miltner S. (2015) Effect of gibberellic acid on germination capacity and emergence rate of Sycamore maple (Acer pseudoplatanus L.) seeds. Forest Science 61(8): 325-331.

Su PH, Li HM. (2008) Arabidopsis stromal 70-kD heat shock proteins are essential for plant development and important for thermotolerance of germinating seeds. Plant physiology 146(3): 1231-1241.

Sun XL, Yu QY, Tang LL, Ji W, Bai X, Cai H, Zhu YM. (2013) GsSRK, a G-type lectin S-receptor-like serine/threonine protein kinase, is a positive regulator of plant tolerance to salt stress. Plant Physiology 170(5), 505-515.

Sung HG, Shin HT, Ha JK, Lai HL, Cheng KJ, Lee, JH. (2005) Effect of germination temperature on characteristics of phytase production from barley. Bioresource Technology 96(11): 1297-1303.

Takesawa T, Ito M, Kanzaki H, Kameya N, Nakamura I. (2002) Over-expression of glutathione S-transferase in transgenic rice enhances germination and growth at low temperature. Molecular Breeding 9(2): 93-101.

Tatematsu K, Nakabayashi K, Kamiya Y, Nambara E. (2008). Transcription factor AtTCP14 regulates embryonic growth potential during seed germination in Arabidopsis thaliana. The Plant Journal 53(1): 42-52.

Loading [MathJax]/jax/output/CommonHTML/fonts/TeX/fontdata.js

Page 22/27 
Teter SA, Sutton KB, Emme B. (2014) Enzymatic processes and enzyme development in biorefining. Advances in Biorefıneries 199-233.

Turner S.D. (2014) qqman: an R package for visualizing GWAS results using QQ and manhattan plots. Biorxiv 005165.

Ullah H, Chen JG, Wang S, Jones AM. (2002) Role of a heterotrimeric G protein in regulation of Arabidopsis seed germination. Plant Physiology 129(2): 897-907.

Vaattovaara A, Brandt B, Rajaraman S, Safronov O, Veidenberg A, Luklová M, Kangasjärvi J, Löytynoja A., Hothorn M, Salojärvi J, Wrzaczek M. (2019) Mechanistic insights into the evolution of DUF26-containing proteins in land plants. Communications biology 2(1): 1-18.

Vijayakumar KR, Gowda LR. (2012) Temporal expression profiling of lipase during germination and rice caryopsis development. Plant Physiology and Biochemistry 57: 245-253.

Voegele A, Linkies A, Muller K, Leubner-Metzger G. (2011) Members of the gibberellin receptor gene family GID1 (GIBBERELLIN INSENSITIVE DWARF1) play distinct roles during Lepidium sativum and Arabidopsis thaliana seed germination. J Exp Bot 62: 5131-5147.

Wang D, Liu H, Wang H, Zhang P, Shi C. (2020) A novel sucrose transporter gene IbSUT4 involves in plant growth and response to abiotic stress through the ABF-dependent ABA signaling pathway in Sweet potato. BMC Plant Biology 20: 1-15.

Wang GM, Yin H, Qiao X, Tan X, Gu C, Wang BH, Zhang SL. (2016) F-box genes: genome-wide expansion, evolution and their contribution to pollen growth in pear (Pyrus bretschneideri). Plant Science 253: 164-175.

Wang ZF, Wang JF, Bao YM, Wang FH, Zhang HS. (2010) Quantitative trait loci analysis for rice seed vigor during the germination stage. Journal of Zhejiang University Science 11(12): 958-964.

Wickham H. (2016) ggplot2: Elegant Graphics for Data Analysis. Springer-Verlag New York. Complete book, edited.

Wilson RL, Kim H, Bakshi A, Binder BM. (2014) The ethylene receptors ETHYLENE RESPONSE1 and ETHYLENE RESPONSE2 have contrasting roles in seed germination of Arabidopsis during salt stress. Plant Physiology 165(3): 1353-1366.

Yamagishi K, Tatematsu K, Yano R, Preston J, Kitamura S, Takahashi H, Nambara, E. (2009) CHOTTO1, a double AP2 domain protein of Arabidopsis thaliana, regulates germination and seedling growth under excess supply of glucose and nitrate. Plant and Cell Physiology 50(2), 330-340.

Yan H, Luo Y, Jiang Z, Wang F, Zhou B, Xu Q. (2016) Cloning and expression characterization of four annexin genes during germination and abiotic stress in Brassica rapa subsp. rapa 'Tsuda'. Plant Molecular Biology Reporter 34(2): 467-482.

Yang B, Song Z, Li C, Jiang J, Zhou Y, Wang R, Fan LM. (2018) RSM1, an Arabidopsis MYB protein, interacts with $\mathrm{HY} 5 / \mathrm{HYH}$ to modulate seed germination and seedling development in response to abscisic acid and salinity. PLOS Genetics 14(12): 1007839.

Loading [MathJax]/jax/output/CommonHTML/fonts/TeX/fontdata.js 


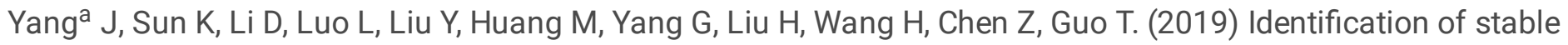
QTLs and candidate genes involved in anaerobic germination tolerance in rice via high-density genetic mapping and RNA-Seq. BMC Genomics 20(1): 1-15.

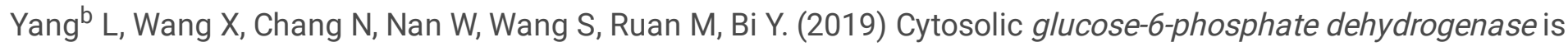
involved in seed germination and root growth under salinity in Arabidopsis. Frontiers in Plant Science 10: 182.

Yi F, Wang Z, Baskin CC, Baskin JM, Ye R, Sun H, Zhang Y, Ye X, Liu G, Yang X, Huang, Z. (2019) Seed germination responses to seasonal temperature and drought stress are species-specific but not related to seed size in a desert steppe: Implications for effect of climate change on community structure. Ecology and Evolution 9(4): 2149-2159.

Yonekura-Sakakibara K, Higashi Y, Nakabayashi R. (2019) The origin and evolution of plant flavonoid metabolism. Frontiers in Plant Science 10: 943.

Zaynab M, Pan D, Fatima M, Chen S, Chen W. (2018) Transcriptomic approach to address low germination rate in Cyclobalnopsis gilva seeds. South African Journal of Botany 119: 286-294.

Zeng P, Zhu P, Qian L, Qian X, Mi Y, Lin Z, Cheng J. (2020) Identification and fine mapping of a novel qGR6. 2 locus controlling rice salt tolerance during seed germination. doi: 10.21203/rs.3.rs-24631/v2.

Zhang D, Wang B, Zhao J, Zhao X, Zhang L, Liu D, Li A. (2015) Divergence in homoeolog expression of the grain length-associated gene GASR7 during wheat allohexaploidization. The Crop Journal 3(1): 1-9.

Zhang GZ, Jin SH, Jiang XY, Dong RR, Li P, Li YJ, Hou BK. (2016) Ectopic expression of UGT75D1, a glycosyltransferase preferring indole-3-butyric acid, modulates cotyledon development and stress tolerance in seed germination of Arabidopsis thaliana. Plant Molecular Biology 90(1-2): 77-93.

Zhang H, Zhang J, Xu Q, Wang D, Di H, Huang J, Yang X, Wang Z, Zhang L, Dong L, Wang Z, Zhou Y. (2020) Identification of candidate tolerance genes to low-temperature during maize germination by GWAS and RNAseqapproaches. BMC Plant Biology 20(1): 1-17.

Zhang L, Tian LH, Zhao JF, Song Y, Zhang CJ, Guo Y. (2009) Identification of an apoplastic protein involved in the initial phase of salt stress response in rice root by two-dimensional electrophoresis. Plant Physiology 149(2): 916928.

Zhang T, Zhao Y, Wang Y, Liu Z, Gao C. (2018) Comprehensive analysis of MYB gene family and their expressions under abiotic stresses and hormone treatments in Tamarix hispida. Frontiers in Plant Science 9: 1303.

Zhang Z, Ersoz E, Lai CQ, Todhunter RJ, Tiwari HK, Gore MA, Bradbury PJ, Yu H, Arnett DK, Ordovas MJ, Buckler ES. (2010) Mixed linear model approach adapted for genome-wide association studies. Nature Genetics 42(4): 355-360.

Zhao K, Tung W, Eizenga C, Wright H, Ali L, Price H, Norton J, Islam R, Reynolds A, Mexey J, McClung A, Bustamante D, Mccouch S. (2011) Genome-wide association mapping reveals a rich genetic architecture of complex traits in Oryza sativa L. Nature Communications 2(1): 1-10.

Zhao P, Hou S, Guo X, Jia J, Yang W, Liu Z, Cheng L. (2019) A MYB-related transcription factor from sheepgrass, LCMYB2, promotes seed germination and root growth under drought stress. BMC Plant Biology 19(1): 1-15.

Loading [MathJax]/jax/output/CommonHTML/fonts/TeX/fontdata.js

Page $24 / 27$ 
Zhou YP, Wu JH, Xiao WH, Chen W, Chen QH, Fan T, Tian CE. (2018) Arabidopsis IQM4, a novel calmodulin-binding protein, is involved with seed dormancy and germination in Arabidopsis. Frontiers in Plant Science 9: 721.

\section{Figures}
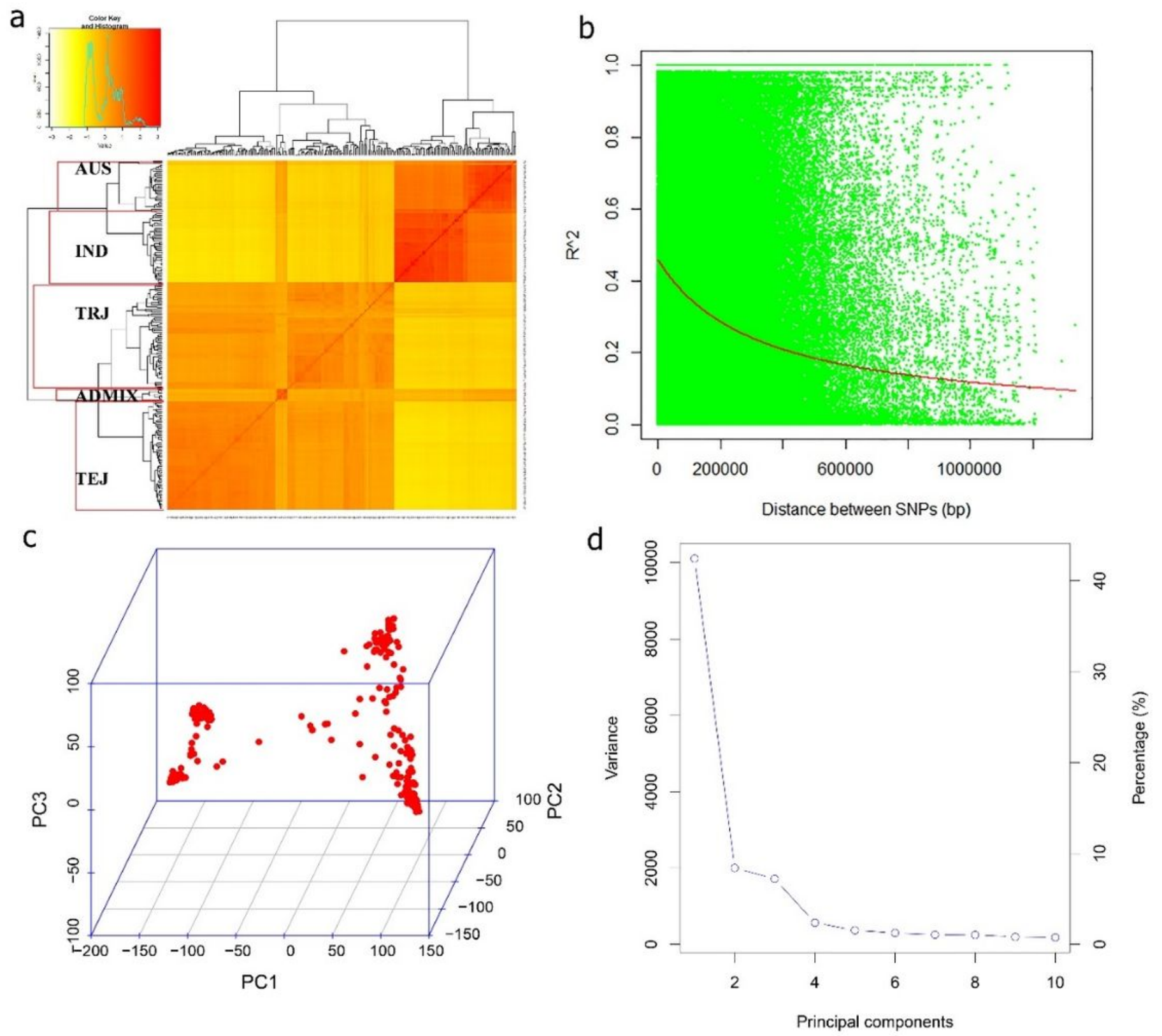

\section{Figure 1}

Kinship, LD decay of the whole population, principal components (PC). a) Heatmap of kinship matrix of 220 rice accessions using SNPs data. Red indicates the highest correlation between pairs of individuals and yellow indicates the lowest correlation. A hierarchical clustering tree based on the pairwise kinship values for all accessions is displayed along the top and left axes. b) population structure of rice germplasm collection as reflected by PCs. First two PCs explain $8.5 \%$ and $7.4 \%$ of the variations, respectively. The third PC explains $2.6 \%$ of the variation; C) LD decay of genome-wide association study (GWAS) population, each dot represents LD (r2) between a pair of SNPS, Loading [MathJax]/jax/output/CommonHTML/fonts/TeX/fontdata.js he regression used to describe the relationship between 
the pairwise distance and r2. Significant LD decay was observed in population; d) Scree plot from GAPIT showing the selection of PCs for association study and results showed three main groups.
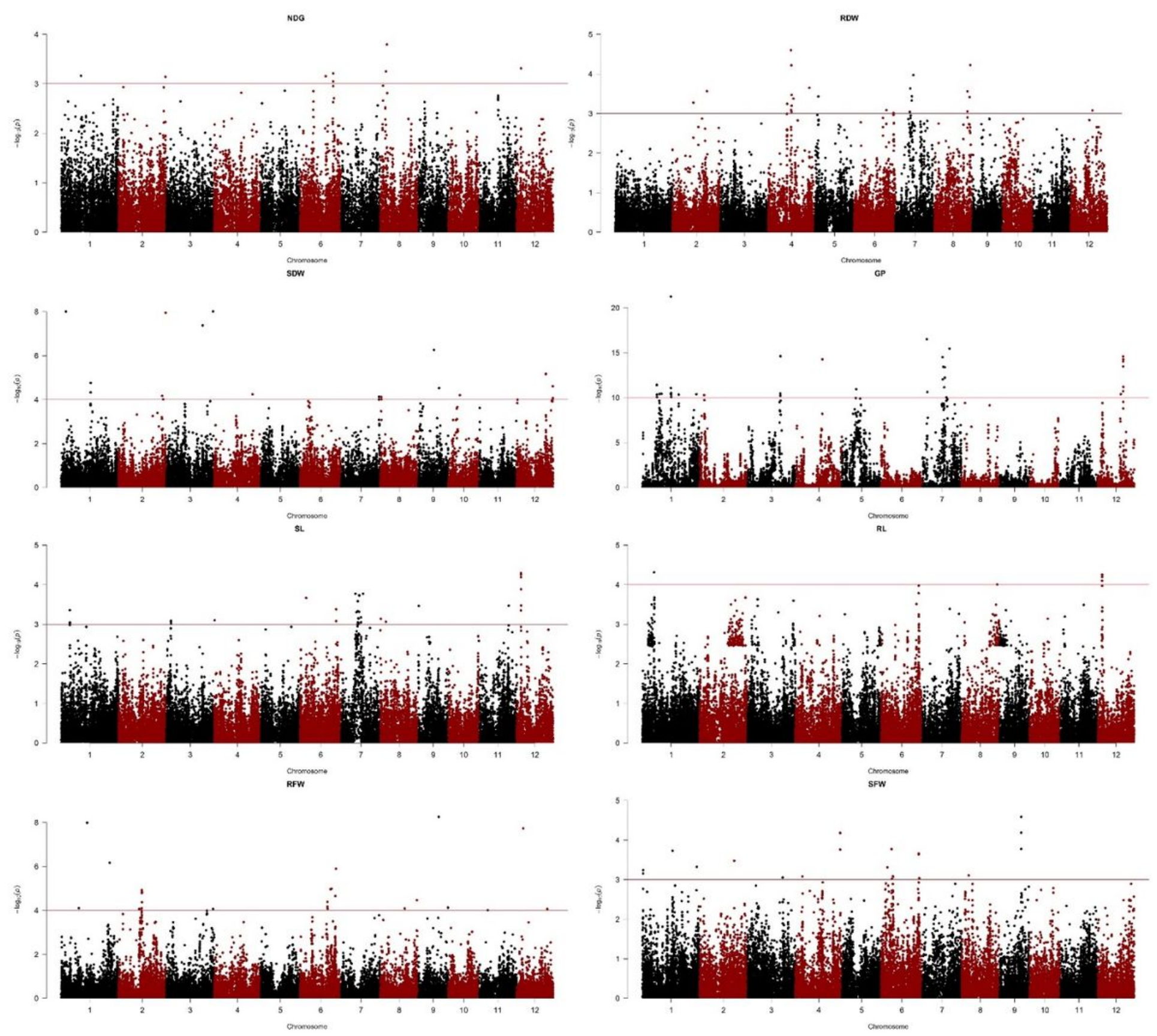

Figure 2

Manhattan plots of germination data from GWAS using the MLM model. The-log10 (p-values) from the GWAS were plotted according to genomic position on each of the 12 rice chromosome in left side of each Manhattan plot. a) NDG, b) RDW, c(SDW, d) GP, e) SL, f) RL, g) RFW, h) SFW. 


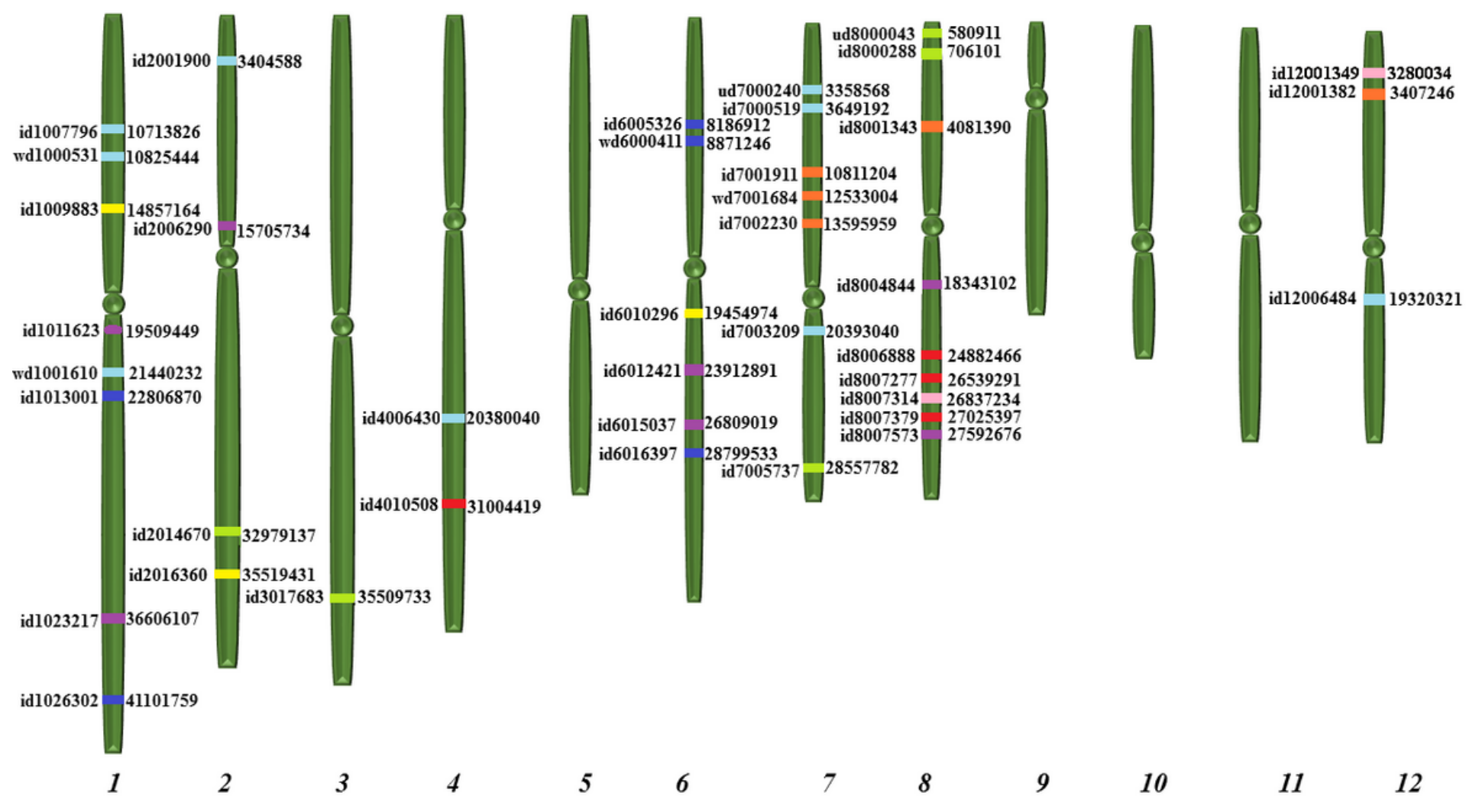

Figure 3

Schematic representation of the 12 rice linkage groups analyzed for genome-wide association scan for germination traits. On the right side of each chromosome the marker position is shown, and on the left, the marker Id is presented. Yellow dots are the associated SNPs resulted from GWAS for NDG, red dots for RDW, green dots for SDW, blue dots for GP, orange dots for SL, pink dots for RL, purple dot for RFW, dark blue dot for SFW. Figure is drawn manually and scaled to reality.

\section{Supplementary Files}

This is a list of supplementary files associated with this preprint. Click to download.

- Supplementaryfigures.docx

- supplementarydataS1.xlsx 